\title{
Pyrolysis of Tall Oil-Derived Fatty and Resin Acid Mixtures
}

\author{
Hanna Lappi ${ }^{1}$ and Raimo Alén ${ }^{2}$ \\ ${ }^{1}$ Kannus Research Unit, Finnish Forest Research Institute, Silmäjärventie 2, 69100 Kannus, Finland \\ ${ }^{2}$ Laboratory of Applied Chemistry, Department of Chemistry, University of Jyväskylä, P.O. Box 35, FI-40014, Finland
}

Correspondence should be addressed to Hanna Lappi, hanna.lappi@metla.fi

Received 4 April 2012; Accepted 23 May 2012

Academic Editors: M. Garcia-Perez and A. Stoppato

Copyright ( 2012 H. Lappi and R. Alén. This is an open access article distributed under the Creative Commons Attribution License, which permits unrestricted use, distribution, and reproduction in any medium, provided the original work is properly cited.

\begin{abstract}
Neutralised mixtures of tall oil-derived fatty acids and resin acids were separately pyrolysed (at $750^{\circ} \mathrm{C}$ for $20 \mathrm{~s}$ ) by pyrolysis gas chromatography with mass-selective and flame ionisation detection (Py-GC/MSD/FID) to clarify their thermochemical behaviour. The pyrolysate of fatty acid salts characteristically contained high amounts of unsaturated aliphatic hydrocarbons and minor amounts of monoaromatics, whereas the pyrolysis of resin acid salts mainly resulted in the formation of aromatics with up to three benzene rings and only in very low amounts of aliphatic hydrocarbons. The data obtained are useful when considering the suitability of various tall oil products containing fatty and resin acid fractions for the production of biofuels and chemicals via pyrolysis.
\end{abstract}

\section{Introduction}

Both fatty acid and resin acid (i.e., tricyclic diterpenoids) components occur in the initial oleoresin fraction of coniferous wood species [1]. In the kraft pulping industry, tall oil soap, containing mainly the sodium salts of these acids, is removed by skimming from the spent cooking liquor "black liquor" during its evaporation before combustion in a recovery furnace to produce energy and recover the inorganic cooking chemicals [2]. Traditionally, the fatty and resin acids are liberated by adding sulphuric acid to yield crude tall oil (CTO, the average yield is in the range of 30 to $50 \mathrm{~kg} \mathrm{ton}^{-1}$ of pulp), which is then purified and fractionated by vacuum distillation. The main fractions and their mass proportions are light oil (10\% to $15 \%$ ), fatty acids (20\% to $40 \%)$, rosin ( $25 \%$ to $35 \%)$, and pitch residue (20\% to $30 \%)$.

Various commercial fatty acid products from tall oil (TOFA) are available [3]. In general, monoenoic oleic $\left(\mathrm{C}_{18: 1}\right)$ and dienoic linoleic $\left(\mathrm{C}_{18: 2}\right)$ acids are common in most TOFA products, although during kraft pulping, the original dienoic and trienoic fatty acids with cis configuration are partly isomerised to acids with conjugated double bonds with mainly cis-trans configuration [4]. On the other hand, during kraft pulping as well as during the acidulation of tall oil soap, a general shift of fatty acid composition towards a lower degree of unsaturation has been reported [5]. The predominating resin acids in commercial tall oil rosin (TOR) are the abietane- and pimarane-type diterpenoids (Figure 1). The principal change in this fraction occurring during kraft pulping is the partial conversion of levopimaric acid into abietic acid. Furthermore, during tall oil distillation, some double-bond isomerisation of both abietane- and pimaranetype acids, disproportionation of abietadienoic acids, and dehydrogenation of abietadienoic and dehydroabietic acids take place [6]. However, the dominant reactions responsible for the losses of original resin acids include decarboxylation together with the dehydration and polymerisation of all acid types.

During the last two decades, various common vegetable oils have aroused considerable interest as potential sources of biofuels [8-10]. The governing idea has been to produce pyrolytically hydrocarbon-rich mixtures resembling petroleum. In our earlier investigations, the thermochemical behaviour of common fatty acid $\left(\mathrm{C}_{18}, \mathrm{C}_{18: 1}\right.$, and $\left.\mathrm{C}_{18: 2}\right)$ sodium salts [11], vegetable oil (palm, olive, rapeseed and castor oils) soaps [12], and CTO soap [13] was clarified under pyrolytic conditions.

Other commercial processes for conversion of vegetable oils into liquid fuels include, for example, transesterification and hydroprocessing to produce, respectively, fatty acid esters and linear hydrocarbons [14-16]. However, one of the main drawbacks of hydroprocessing is that it must be 


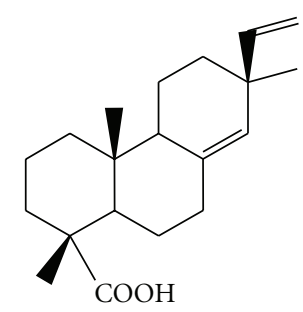

Pimaric acid

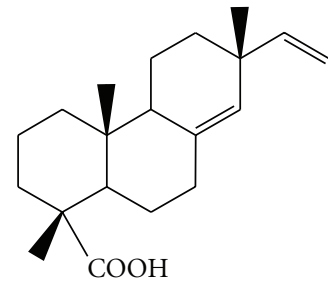

Sandaracopimaric acid

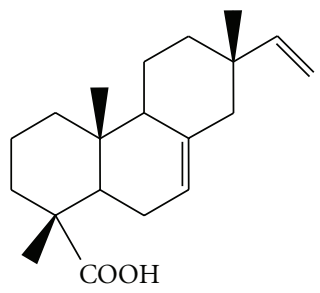

Isopimaric acid<smiles>CC(C)C1=CC2=CCC3[C@](C)(C(=O)O)CCC[C@]3(C)C2CC1</smiles>

Abietic acid<smiles>CC(C)C1=CC[C@H]2C(=C1)CCC1[C@@](C)(C(=O)O)CCC[C@@]12C</smiles>

Levopimaric acid

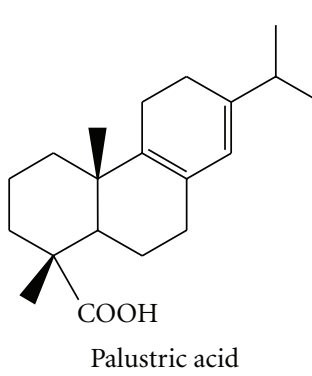

Palustric acid<smiles>CC(C)=C1C=C2CCC3[C@](C)(C(=O)O)CCC[C@]3(C)[C@H]2CC1</smiles>

Neoabietic acid<smiles>CC(C)c1ccc2c(c1)CCC1[C@@](C)(C(=O)O)CCC[C@]21C</smiles>

Dehydroabietic acid

FIGURE 1: Chemical structures of the most common resin acids [7].

conducted under high pressure. In addition, conventional hydroprocesses are usually quite expensive (large reactors and compressors, costs for recycle of both feed and hydrogen, as well as cost to shut down and to replace and/or regenerate deactivated catalyst) [17]. Additional inefficiencies are due to recycle of feed because of low conversions as well as to impurities containing sulphur, nitrogen, metals, and aromatics.

Commonly practiced transesterification has some drawbacks including the requirement of a large amount of alcohol, typically methanol, which is usually derived from natural gas or other fossil fuel sources $[14,18]$. The formation of a low value by-product in the form of glycerol is also a problem, at least until there are enough facilities for its refining. Additionally, the heating values are lower than those of conventional diesel fuels.

The analysis performed by U.S. Department of Energy [19] concludes that the production of hydrocarbon motor fuels from biomass via the pyrolysis route is economically attractive. The cost becomes even more favourable if the facility can be closely associated with an existing petroleum refinery. Fast pyrolysis is a simple, efficient (high thermal efficiency), low fossil fuel input, and inexpensive technology $[20,21]$. The by-products of char and gas can be used within the process to provide process heat requirements [22]. In this way, there are no waste streams other than from flue gas and ash.

The main objective of this study was to obtain more detailed data on the thermochemical reactions taking place during the pyrolysis of the main components in tall oilderived products. For this purpose, neutralised fractions of TOFA and TOR were selected. Our tentative findings [13] indicated that due to the remarkable formation of complicated aromatics, resin acids would have, for example, a negative effect on the quality of the product during production of diesel-type biofuels. This study was based on earlier findings [11] that, when pyrolysing soaps (i.e., as sodium salts of acids) instead of using free acids as feedstocks, pyrolysis can be controlled more readily. This also means that, for example, in the case of tall oil-based feedstocks, pyrolysis can be applied directly to tall oil soap and no external sulphuric acid is needed for acidulation.

\section{Experimental}

2.1. Chemicals and Tall Oil Samples. The compounds used as internal standards in the gas chromatographic (GC) analysis of the extractives were heneicosanoic acid (99\%, Sigma) and betulinol ( $\geq 98 \%$, Sigma). The external standard used in the quantitative pyrolysis experiments was adamantane $(>99 \%$, Fluka) in benzene (>99\%, Fluka). Solvents used in the sample preparation of the extractives were analytical grade acetone (BDH), methyl tert-butyl ether (MTBE) (Lab$\mathrm{Scan})$, and analytical grade pyridine (BDH). The silylation reagents bis(trimethylsilyl)trifluoroacetamide (BSTFA) and trimethylchlorosilane (TMCS) were from Regis Technologies.

The chemicals used in the determination of saponification values were potassium hydroxide ( $\geq 85 \%$, Riedel de Haën), sodium hydroxide ( $\geq 99 \%$, Fluka), hydrochloric acid ( $\geq 37 \%$, Riedel de Haën), denatured alcohol BA ( $99.5 \mathrm{w}-\%$, Altia), and phenolphthalein (Merck). Water was obtained from a Millipore Milli-Q water system.

TOFA containing about $1.4 \%$ unsaponifiables and TOR containing about $3.5 \%$ unsaponifiables were the products of Forchem Oy.

2.2. Analysis of Tall Oil Acid Mixtures. For the analysis of extractive constituents, the samples were diluted in acetone $\left(0.5 \mathrm{mg} \mathrm{mL}^{-1}\right)$ and derivatised for GC with a mixture of BSTFA and TMCS (99:1, resp.). Derivatisation of samples was performed by keeping them at $70^{\circ} \mathrm{C}$ for one hour. Quantitative analysis of the individual compounds was carried 
out on an Agilent 6850 Series GC System with an Equity$5(30 \mathrm{~m} \times 0.32 \mathrm{~mm}$, film thickness $0.25 \mu \mathrm{m})$ column. The injector temperature was $290^{\circ} \mathrm{C}$ and the detector temperature was $300^{\circ} \mathrm{C}$. The GC oven temperature programme was $1.5 \mathrm{~min}$ at $100^{\circ} \mathrm{C}$, followed by an increase of $6^{\circ} \mathrm{C} \mathrm{min}^{-1}$ to $180^{\circ} \mathrm{C}, 10 \mathrm{~min}$ at $180^{\circ} \mathrm{C}$, an increase of $4^{\circ} \mathrm{C} \mathrm{min}^{-1}$ to $290^{\circ} \mathrm{C}$, and $20 \mathrm{~min}$ at $290^{\circ} \mathrm{C}$. Qualitative analysis of the individual components was performed with an Agilent 6890 Series GC System equipped with a 7683 injector and an Agilent 5973 mass selective detector (MSD). The capillary column used was an HP-5MS $(30 \mathrm{~m} \times 0.32 \mathrm{~mm}$, film thickness $0.25 \mu \mathrm{m})$ and the GC oven temperature programme was the same as that used in the quantitative analyses.

Saponification values for the acid mixtures were determined according to the TAPPI standard T621 cm-01.

2.3. Pyrolysis Experiments. TOFA and TOR were both saponified with sodium hydroxide (the amount was 1.5 times the equivalent amount) prior to pyrolysis. Soap samples were pyrolysed in quartz tubes at a heating rate of $1000^{\circ} \mathrm{C} \mathrm{s}^{-1}$ using a CDS Pyroprobe 1000 heated-filament pyrolyser coupled to an HP 5890 II gas chromatograph (Py-GC). The column was a ZB-5HT capillary GC column (30 $\mathrm{m} \times$ $0.25 \mathrm{~mm}$, film thickness $0.25 \mu \mathrm{m}$ ). Detection was carried out with either an HP 5972 mass selective detector (MSD, qualitative analyses) or an HP $5890 \mathrm{GC} /$ flame ionisation detection (FID quantitative analyses). The sample size for qualitative analysis was about $3 \mathrm{mg}$ and for quantitative analysis about $1 \mathrm{mg}$. The Py-GC interface temperature was $250^{\circ} \mathrm{C}$ and the injector temperature $280^{\circ} \mathrm{C}$. Pyrolysis parameters were chosen according to the results of previous research $[12,13]$. In each experiment, the pyrolysis temperature was $750^{\circ} \mathrm{C}$ and the temperature was kept constant for $20 \mathrm{~s}$. The GC oven temperature was $5 \mathrm{~min}$ at $35^{\circ} \mathrm{C}$, an increase of $5^{\circ} \mathrm{C} \mathrm{min}^{-1}$ to $125^{\circ} \mathrm{C}, 3^{\circ} \mathrm{C} \mathrm{min}^{-1}$ to $285^{\circ} \mathrm{C}, 5^{\circ} \mathrm{C} \mathrm{min}^{-1}$ to $380^{\circ} \mathrm{C}$, and finally $5 \mathrm{~min}$ at $360^{\circ} \mathrm{C}$. Helium was used as the carrier gas and as an inert atmosphere in the pyrolysis interface. The carrier gas flow rate was kept at $1 \mathrm{~mL} \mathrm{~min}^{-1}$ during the gas chromatographic analysis.

Due to the multiplicity of pyrolysis products, the identification of all constituents in pyrolysates appeared to be impossible only by the retention time with respect to some internal standards. For this reason, a proper interpretation of the mass spectra of the pyrolysis products was based on a commercial database, Wiley $7 \mathrm{n}$, together with the recognition of fragmentation patterns as well as our earlier results [11-13]. Only quality matches of above $85 \%$ were included.

The calibration curve for quantitative determination of the pyrolysis products was determined by the pyrolysis of adamantane dissolved in benzene. The calibration was performed using a similar method to that used by Bocchini et al. [23] when adding the internal standard for pyrolysis. Solutions of adamantane in the 40 to $110 \mu \mathrm{g} \mathrm{mL}^{-1}$ range were carefully added to a quartz capillary tube, which was immediately inserted into the Py-GC interface. After an equilibration period of $30 \mathrm{~s}$, pyrolysis was performed. Six different concentrations were pyrolysed using the same parameters as for the samples. Two replicates were made for each concentration. The correlation coefficient $\left(R^{2}\right)$ of the calibration curve obtained was 0.990 . Due to the multitude of peaks in the vegetable oil pyrolysates, adamantane was only used as an external standard. This quantification was used to calculate the product yields.

\section{Results and Discussion}

3.1. Raw Materials. The total amounts of fatty acids and resin acids detected in TOFA were about $94 \%$ and $3 \%$, respectively. Values were slightly different from those given by the manufacturer ( $97 \%$ and $1.7 \%$, resp.), which was probably due to our inaccurate compound quantification (i.e., in all cases, the response factors used between the GC peak areas derived from the internal standards and compounds were equal to 1) and a fact that not all peaks (the amount of unidentified peaks was about 3\%, Table 1) could be identified. Due to double-bond rearrangements, four different isomers of conjugated $\mathrm{C}_{18: 2}$ acids were found. The main fatty acid components were unsaturated linoleic $\left(\mathrm{C}_{18: 2}\right)$, oleic $\left(\mathrm{C}_{18: 1}\right)$, and linolenic $\left(\mathrm{C}_{18: 3}\right)$ acids.

The composition of resin acids in TOR differed significantly from that in CTO, indicating various decomposition and isomerisation reactions during distillation [24]. For this reason, the amount of unidentified peaks (mainly various resin acid derivatives) was also relatively high (about $10 \%$ of the total peak areas, Table 1). The total amounts of fatty acids and resin acids detected in TOR were about 3\% and $86 \%$, respectively. These values differed from those given by the manufacturer (92\% and 3.5\%), probably because of the limitation of the analysis method mentioned above. The main resin acid components were abietane-type acids, abietic, dehydroabietic, and palustric acids.

3.2. Pyrolysis of Soap Mixtures. All the pyrolysates contained significant amounts of highly volatile products marked as " $\mathrm{C}_{3}-\mathrm{C}_{5}$ compounds" in Figure 2, primarily corresponding to both alkenes and alkanes. However, due to the low resolution of these numerous low-molecular-mass compounds, their proper identification was not possible with the apparatus used.

The pyrolysis of neutralised TOFA resulted in a high amount of unsaturated aliphatic hydrocarbons (Figures 2 and 3, Table 2), although some aromatics with one benzene ring were also formed (Figure 2, Table 3 ). The most prominent fractions were alkenes $\left(\mathrm{C}_{6}-\mathrm{C}_{12}\right)$ and alkadienes $\left(\mathrm{C}_{11}\right.$, $\mathrm{C}_{12}$ and $\mathrm{C}_{17}$ ) together with benzene and methylbenzene. The alkadienes can be considered representatives of the typical reaction products derived, for example, from oleic acid $\left(\mathrm{C}_{18: 1}\right)$. Due to the lower dissociation energies of allyl bonds, the presence of the double bond in the alkyl chain favours the homolytic $\mathrm{C}-\mathrm{C}$ cleavage at the allyl position rather than the homolytic $\mathrm{C}-\mathrm{C}$ cleavage adjacent to the carboxylic group [25]. For this reason, a relatively significant amount of 1undecene was formed from oleic acid. The additional double bonds in the alkyl chain (cf., linoleic $\left(\mathrm{C}_{18: 2}\right)$ and linolenic $\left(\mathrm{C}_{18: 3}\right)$ acids) favoured cyclisation and aromatisation, thus 


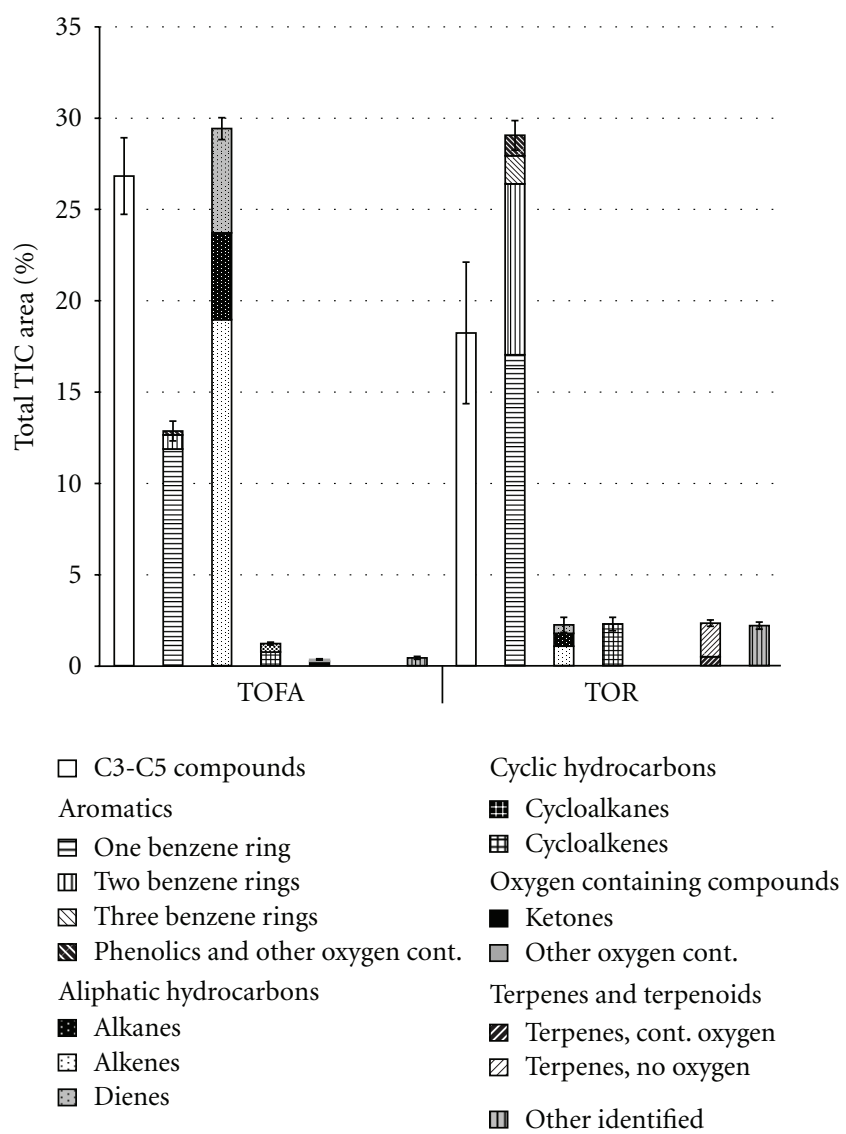

Figure 2: Percentage of the TIC peak areas of various pyrolysis products groups and the standard deviation of the results.

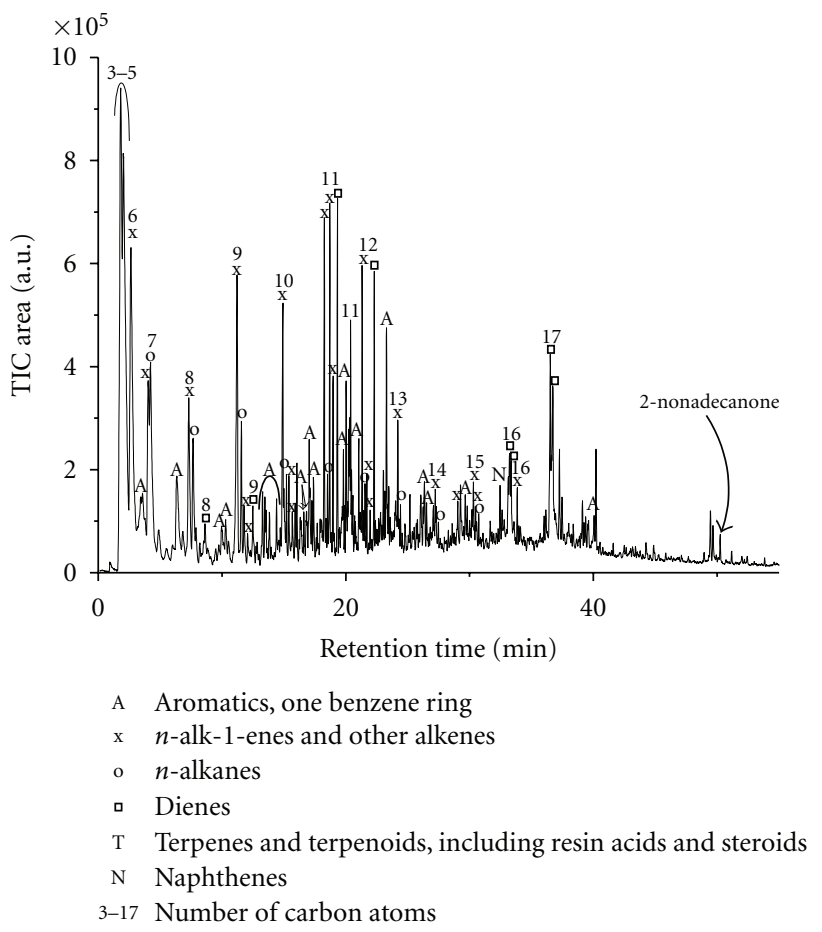

FIgURE 3: The main products formed in the pyrolysis experiments $\left(750^{\circ} \mathrm{C}\right.$ and $\left.20 \mathrm{~s}\right)$ with neutralised TOFA. Numbers indicate the amount of carbon atoms in a molecule.
TABLE 1: Composition of total extractives ( $\%$ of the total).

\begin{tabular}{lccc}
\hline & TOFA & TOR & Formula \\
\hline Fatty acids & & & \\
Palmitic acid & 0.1 & $*$ & $\mathrm{C}_{16} \mathrm{H}_{32} \mathrm{O}_{2}$ \\
Margaric acid & 0.1 & & $\mathrm{C}_{17} \mathrm{H}_{34} \mathrm{O}_{2}$ \\
17:0 anteiso & 0.1 & & $\mathrm{C}_{17} \mathrm{H}_{34} \mathrm{O}_{2}$ \\
Linolenic acid & 8.5 & & $\mathrm{C}_{18} \mathrm{H}_{30} \mathrm{O}_{2}$ \\
Linoleic acid & 48.1 & & $\mathrm{C}_{18} \mathrm{H}_{32} \mathrm{O}_{2}$ \\
Oleic acid & 24.6 & & $\mathrm{C}_{18} \mathrm{H}_{34} \mathrm{O}_{2}$ \\
Stearic acid & 3.5 & $*$ & $\mathrm{C}_{18} \mathrm{H}_{36} \mathrm{O}_{2}$ \\
18:2 (conjugated) & 0.8 & & $\mathrm{C}_{18} \mathrm{H}_{32} \mathrm{O}_{2}$ \\
18:2 (conjugated) & 1.8 & & $\mathrm{C}_{18} \mathrm{H}_{32} \mathrm{O}_{2}$ \\
18:2 (conjugated) & 2.4 & & $\mathrm{C}_{18} \mathrm{H}_{32} \mathrm{O}_{2}$ \\
18:3 (conjugated) & 0.9 & & $\mathrm{C}_{18} \mathrm{H}_{30} \mathrm{O}_{2}$ \\
10-Nonadecenoic acid & 1.1 & & $\mathrm{C}_{19} \mathrm{H}_{36} \mathrm{O}_{2}$ \\
Nonadecanoic acid & 0.2 & & $\mathrm{C}_{19} \mathrm{H}_{38} \mathrm{O}_{2}$ \\
Eicosatrienoic acid & 1.2 & & $\mathrm{C}_{20} \mathrm{H}_{34} \mathrm{O}_{2}$ \\
Eicosadienoic acid & 0.2 & & $\mathrm{C}_{20} \mathrm{H}_{36} \mathrm{O}_{2}$ \\
Eicosenoic acid & 0.2 & & $\mathrm{C}_{20} \mathrm{H}_{38} \mathrm{O}_{2}$ \\
Arachidic acid & 0.2 & 0.4 & $\mathrm{C}_{20} \mathrm{H}_{40} \mathrm{O}_{2}$ \\
Behenic acid & & 2.2 & $\mathrm{C}_{22} \mathrm{H}_{44} \mathrm{O}_{2}$ \\
Lignoseric acid & & 0.5 & $\mathrm{C}_{24} \mathrm{H}_{48} \mathrm{O}_{2}$ \\
\hline$\sum$ & & & \\
\hline Resin acids & & & \\
\hline & & &
\end{tabular}

Resin acids

Secohydroabietic acid

8,15-Isopimaridien-18-oic acid

* $\quad \mathrm{C}_{20} \mathrm{H}_{30} \mathrm{O}_{2}$

8,15-Pimaradien-18-oic acid

* $\quad 1.3 \quad \mathrm{C}_{20} \mathrm{H}_{30} \mathrm{O}_{2}$

Pimaric acid

$1.8 \quad 1.1 \quad \mathrm{C}_{20} \mathrm{H}_{30} \mathrm{O}_{2}$

Sandaracopimaric acid

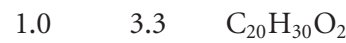

Isopimaric acid

$\begin{array}{lll}0.1 & 1.2 & \mathrm{C}_{20} \mathrm{H}_{30} \mathrm{O}_{2}\end{array}$

Palustric acid

$0.1 \quad 4.3 \quad \mathrm{C}_{20} \mathrm{H}_{30} \mathrm{O}_{2}$

$\begin{array}{lll}\text { Dihydroabietic acid } & 0.5 & \mathrm{C}_{20} \mathrm{H}_{32} \mathrm{O}_{2}\end{array}$

$\begin{array}{lll}\text { Levopimaric acid } & 0.3 & \mathrm{C}_{20} \mathrm{H}_{30} \mathrm{O}_{2}\end{array}$

Dehydroabietic acid $\quad 21.4 \quad \mathrm{C}_{20} \mathrm{H}_{28} \mathrm{O}_{2}$

$\begin{array}{lll}\text { Abietic acid } & 36.2 & \mathrm{C}_{20} \mathrm{H}_{30} \mathrm{O}_{2}\end{array}$

Abietatetraenoic acid $\quad 1.0 \quad \mathrm{C}_{21} \mathrm{H}_{28} \mathrm{O}_{2}$

$\begin{array}{lll}\text { Neoabietic acid } & 1.7 & \mathrm{C}_{20} \mathrm{H}_{30} \mathrm{O}_{2}\end{array}$

$\begin{array}{llll}\text { Isodehydroabietic acid } & * & \mathrm{C}_{20} \mathrm{H}_{30} \mathrm{O}_{2}\end{array}$

Hydroxydehydroabietic acid $\quad 1.2 \quad \mathrm{C}_{20} \mathrm{H}_{28} \mathrm{O}_{3}$

Unidentified hydroxy resin acid $\quad 1.4 \quad \mathrm{C}_{20} \mathrm{H}_{30} \mathrm{O}_{3}$

$\begin{array}{lll}\text { Dihydroxydehydroabietic acid } & 0.3 & \mathrm{C}_{20} \mathrm{H}_{28} \mathrm{O}_{4}\end{array}$

Hydroxy-7-oxodehydroabietic acid $\quad 0.4 \quad \mathrm{C}_{20} \mathrm{H}_{26} \mathrm{O}_{4}$

\begin{tabular}{lll}
\hline$\sum$ & 3.0 & 86.2 \\
\hline Unknown & 3.0 & 10.7
\end{tabular}

*Traces of the compound detected in qualitative analysis, not enough for the quantification.

Abbreviations: TOFA: neutralised tall oil fatty acid mixture and TOR: neutralised tall oil resin acid mixture.

explaining a considerable amount (about 13\% of the total compounds, Figures 2 and 3) of aromatics detected in the TOFA pyrolysate. The amount of various unidentified compounds was about $29 \%$ of the total compounds. 
TABLE 2: Classification ${ }^{\mathrm{a}}$ of aliphatic pyrolysis products (including their formula) from the tall oil studies.

\begin{tabular}{|c|c|}
\hline \multicolumn{2}{|l|}{$n$-Alk-1-enes and other alkenes } \\
\hline 1-Hexene & $\mathrm{C}_{6} \mathrm{H}_{12}$ \\
\hline 1-Heptene & $\mathrm{C}_{7} \mathrm{H}_{14}$ \\
\hline 1-Octene and other octenes ${ }^{\mathrm{b}}$ & $\mathrm{C}_{8} \mathrm{H}_{16}$ \\
\hline 1-Nonene ${ }^{\mathrm{b}}$ and other nonenes ${ }^{\mathrm{b}}$ & $\mathrm{C}_{9} \mathrm{H}_{18}$ \\
\hline 1-Decene ${ }^{\mathrm{b}}$ and other decenes ${ }^{\mathrm{b}}$ & $\mathrm{C}_{10} \mathrm{H}_{20}$ \\
\hline 1-Undecene and other undecenes ${ }^{\mathrm{b}}$ & $\mathrm{C}_{11} \mathrm{H}_{22}$ \\
\hline 1-Dodecene and other dodecenes ${ }^{\mathrm{b}}$ & $\mathrm{C}_{12} \mathrm{H}_{24}$ \\
\hline 1-Tridecene ${ }^{\mathrm{b}}$ and other tridecenes ${ }^{\mathrm{b}}$ & $\mathrm{C}_{13} \mathrm{H}_{26}$ \\
\hline 1-Tetradecene ${ }^{\mathrm{b}}$ and other tetradecenes ${ }^{\mathrm{b}}$ & $\mathrm{C}_{14} \mathrm{H}_{28}$ \\
\hline 1-Pentadecene ${ }^{\mathrm{b}}$ & $\mathrm{C}_{15} \mathrm{H}_{30}$ \\
\hline 1-Hexadecene ${ }^{b}$ & $\mathrm{C}_{16} \mathrm{H}_{32}$ \\
\hline 1-Heptadecene ${ }^{b}$ & $\mathrm{C}_{17} \mathrm{H}_{34}$ \\
\hline \multicolumn{2}{|l|}{ Alkanes } \\
\hline Heptane & $\mathrm{C}_{7} \mathrm{H}_{16}$ \\
\hline Octane & $\mathrm{C}_{8} \mathrm{H}_{18}$ \\
\hline Nonane $^{b}$ & $\mathrm{C}_{9} \mathrm{H}_{20}$ \\
\hline Decane $^{\mathrm{b}}$ & $\mathrm{C}_{10} \mathrm{H}_{22}$ \\
\hline Undecane & $\mathrm{C}_{11} \mathrm{H}_{24}$ \\
\hline Dodecane $^{\mathrm{b}}$ & $\mathrm{C}_{12} \mathrm{H}_{26}$ \\
\hline Tridecane & $\mathrm{C}_{13} \mathrm{H}_{28}$ \\
\hline Tetradecane $^{\mathrm{b}}$ & $\mathrm{C}_{14} \mathrm{H}_{30}$ \\
\hline Pentadecane ${ }^{\mathrm{b}}$ & $\mathrm{C}_{15} \mathrm{H}_{32}$ \\
\hline \multicolumn{2}{|l|}{ Dienes } \\
\hline 2-Methyl-2,3-hexadiene & $\mathrm{C}_{7} \mathrm{H}_{12}$ \\
\hline 2,5-Dimethyl-2,4-hexadiene ${ }^{c}$ & $\mathrm{C}_{8} \mathrm{H}_{14}$ \\
\hline 1,3-Octadiene ${ }^{\mathrm{b}}$ & $\mathrm{C}_{8} \mathrm{H}_{14}$ \\
\hline 1,3-Nonadiene ${ }^{\mathrm{b}}$ & $\mathrm{C}_{9} \mathrm{H}_{16}$ \\
\hline 1,4-Undecadiene $\mathrm{e}^{\mathrm{b}}$ and 2,4-undecadien $\mathrm{e}^{\mathrm{b}}$ & $\mathrm{C}_{11} \mathrm{H}_{20}$ \\
\hline 2,4-Dodecadiene ${ }^{\mathrm{b}}$ & $\mathrm{C}_{12} \mathrm{H}_{22}$ \\
\hline 1,9-Tetradecadiene $\mathrm{b}^{\mathrm{b}}$ & $\mathrm{C}_{14} \mathrm{H}_{26}$ \\
\hline 1,15-Hexadecadiene ${ }^{b}$ & $\mathrm{C}_{16} \mathrm{H}_{30}$ \\
\hline 6,8-Heptadecadiene ${ }^{\mathrm{b}}$ & $\mathrm{C}_{17} \mathrm{H}_{32}$ \\
\hline \multicolumn{2}{|l|}{ Cycloalkanes } \\
\hline Butylcyclopentane $\mathrm{b}^{\mathrm{b}}$ & $\mathrm{C}_{9} \mathrm{H}_{18}$ \\
\hline Nonylcyclopentane ${ }^{\mathrm{b}}$ & $\mathrm{C}_{14} \mathrm{H}_{28}$ \\
\hline Nonylcyclohexane ${ }^{\mathrm{b}}$ & $\mathrm{C}_{15} \mathrm{H}_{30}$ \\
\hline \multicolumn{2}{|l|}{ Cycloalkenes } \\
\hline Methylcyclopentadiene ${ }^{c}$ & $\mathrm{C}_{6} \mathrm{H}_{8}$ \\
\hline 1-Methyl-1,4-cyclohexadiene & $\mathrm{C}_{7} \mathrm{H}_{10}$ \\
\hline 3-Ethenylcyclopentene $\mathrm{b}^{\mathrm{b}}$ & $\mathrm{C}_{7} \mathrm{H}_{10}$ \\
\hline 5,6-Dimethyl-1,3-cyclohexadiene ${ }^{c}$ and & $\mathrm{C}_{8} \mathrm{H}_{12}$ \\
\hline $\begin{array}{l}\text { 1,5-dimethyl-1,4-cyclohexadiene }{ }^{c} \\
1,3,8 \text { - } p \text {-Menthatriene }\end{array}$ & $\mathrm{C}_{10} \mathrm{H}_{14}$ \\
\hline 1,4-Dimethyldihydroazulene $e^{c}$ & $\mathrm{C}_{12} \mathrm{H}_{14}$ \\
\hline \multicolumn{2}{|l|}{ Terpenes and terpenoids } \\
\hline$\alpha$-Terpinene ${ }^{\mathrm{c}}$ & $\mathrm{C}_{10} \mathrm{H}_{16}$ \\
\hline$\Delta^{3}$-Carene $e^{c}$ & $\mathrm{C}_{10} \mathrm{H}_{16}$ \\
\hline Limonene $^{\mathrm{c}}$ & $\mathrm{C}_{10} \mathrm{H}_{16}$ \\
\hline Chamazulene $^{c}$ & $\mathrm{C}_{14} \mathrm{H}_{16}$ \\
\hline 1,4-dimethyl-7-(1-methylethyl)azulene ${ }^{c}$ & $\mathrm{C}_{15} \mathrm{H}_{18}$ \\
\hline Stigmastan-3,5-dien ${ }^{c}$ & $\mathrm{C}_{29} \mathrm{H}_{48}$ \\
\hline \multicolumn{2}{|l|}{ Terpenes and terpenoids containing oxygen } \\
\hline Borneol & $\mathrm{C}_{10} \mathrm{H}_{18} \mathrm{O}$ \\
\hline 1-Methyloestra-1,3,5(10)-trien-18-nor-17-ketone ${ }^{\mathrm{c}}$ & $\mathrm{C}_{18} \mathrm{H}_{22} \mathrm{O}$ \\
\hline \multicolumn{2}{|l|}{ Ketones } \\
\hline 2-Dodecanone $\mathrm{b}^{\mathrm{b}}$ & $\mathrm{C}_{12} \mathrm{H}_{24} \mathrm{O}$ \\
\hline 2-Nonadecanone ${ }^{\mathrm{b}}$ & $\mathrm{C}_{19} \mathrm{H}_{38} \mathrm{O}$ \\
\hline
\end{tabular}

TABle 2: Continued.

\begin{tabular}{|c|c|}
\hline \multicolumn{2}{|l|}{ Other Oxygen containing compounds } \\
\hline 10,12-Hexadecadienal ${ }^{\mathrm{b}}$ & $\mathrm{C}_{16} \mathrm{H}_{28} \mathrm{O}$ \\
\hline $9,12,15$-Octadecatrien-1-ol ${ }^{\mathrm{b}}$ & $\mathrm{C}_{18} \mathrm{H}_{32} \mathrm{O}$ \\
\hline \multicolumn{2}{|l|}{ Others } \\
\hline 1,4-Bis(methylene)cyclohexane $e^{\mathrm{c}}$ & $\mathrm{C}_{8} \mathrm{H}_{12}$ \\
\hline 5-Dodecen-7-yne & $\mathrm{C}_{12} \mathrm{H}_{20}$ \\
\hline $\begin{array}{l}\left.\text { 1-(2'-Methyl- } 1^{\prime} \text {-propenyl }\right)-7-\left(1^{\prime} \text {-propynyl }\right)- \\
\text { tricyclohexane }\end{array}$ & $\mathrm{C}_{8} \mathrm{H}_{12}$ \\
\hline 1-Hexadecyne ${ }^{b}$ & $\mathrm{C}_{16} \mathrm{H}_{30}$ \\
\hline Hexaethylidenecyclohexane ${ }^{c}$ & $\mathrm{C}_{18} \mathrm{H}_{24}$ \\
\hline 10-Demethylsqualene $e^{c}$ & $\mathrm{C}_{19} \mathrm{H}_{48}$ \\
\hline
\end{tabular}

${ }^{a}$ Compounds are listed within each substance group according to their GC retention times.

${ }^{b}$ Only in the pyrolysate of neutralised TOFA.

'Only in the pyrolysate of neutralised TOR.

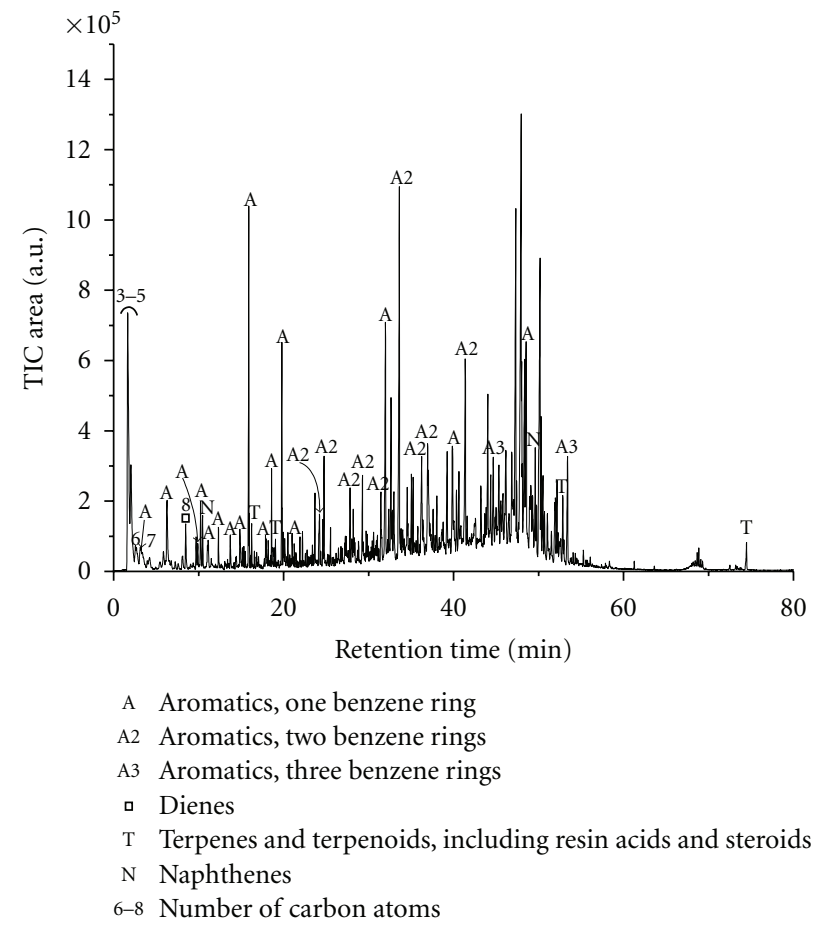

FIGURE 4: The main products formed in the pyrolysis experiments $\left(750^{\circ} \mathrm{C}\right.$ and $\left.20 \mathrm{~s}\right)$ with neutralised TOR. Numbers indicate the amount of carbon atoms in a molecule.

The main compounds in the pyrolysate from the neutralised TOR characteristically comprised various aromatics with one to three benzene rings, while a lower amount of aliphatic hydrocarbons could clearly be detected (Figures 2 and 4 , Tables 2 and 3). In this case, the portion of unknown pyrolysis products was very high (approx., 44\%). However, it could be assumed (based also on MS spectra) that a large portion of these unidentified compounds consist of a wide range of polyaromatic hydrocarbon derivatives. For example, it has been found earlier [26] that the most abundant resin acid-derived pyrolysis products are naphthalene derivatives. Moreover, pyrolysis experiments with abietic acid [27] indicated that besides fragmentation and decarboxylation reactions, dehydrogenation is of importance, suggesting 
TABLE 3: Classification ${ }^{\mathrm{a}}$ of aromatic pyrolysis products (including their formula) from the tall oil studies.

\begin{tabular}{|c|c|}
\hline Aromatics, one benzene ring & \\
\hline Benzene & $\mathrm{C}_{6} \mathrm{H}_{6}$ \\
\hline Toluene & $\mathrm{C}_{7} \mathrm{H}_{8}$ \\
\hline Ethylbenzene & $\mathrm{C}_{8} \mathrm{H}_{10}$ \\
\hline Styrene & $\mathrm{C}_{8} \mathrm{H}_{8}$ \\
\hline$o$-Xylene and $p$-xylene $e^{c}$ & $\mathrm{C}_{8} \mathrm{H}_{10}$ \\
\hline Cumene & $\mathrm{C}_{8} \mathrm{H}_{12}$ \\
\hline Propenylbenzene & $\mathrm{C}_{9} \mathrm{H}_{12}$ \\
\hline Isocumene $\mathrm{b}^{\mathrm{b}}$ & $\mathrm{C}_{9} \mathrm{H}_{12}$ \\
\hline$o$-Ethyltoluene and $m$-ethyltoluene & $\mathrm{C}_{9} \mathrm{H}_{12}$ \\
\hline$\alpha$-Methylstyrol $^{\mathrm{c}}$ & $\mathrm{C}_{9} \mathrm{H}_{10}$ \\
\hline$m$-Vinyltoluene $\mathrm{e}^{\mathrm{b}}$ & $\mathrm{C}_{9} \mathrm{H}_{10}$ \\
\hline 2-Isopropyltoluene & $\mathrm{C}_{10} \mathrm{H}_{14}$ \\
\hline Indane $\mathrm{b}^{\mathrm{b}}$ & $\mathrm{C}_{9} \mathrm{H}_{10}$ \\
\hline Indene & $\mathrm{C}_{9} \mathrm{H}_{8}$ \\
\hline 1,2-Diethylbenzene $\mathrm{e}^{\mathrm{c}}$ & $\mathrm{C}_{10} \mathrm{H}_{14}$ \\
\hline$m$-Propyltoluene $e^{\mathrm{c}}$ and $o$-propyltoluene $\mathrm{e}^{\mathrm{b}}$ & $\mathrm{C}_{10} \mathrm{H}_{14}$ \\
\hline Butylbenzene $e^{b}$ & $\mathrm{C}_{10} \mathrm{H}_{14}$ \\
\hline$\beta$-Dimethylstyrene & $\mathrm{C}_{10} \mathrm{H}_{12}$ \\
\hline 2,5-Dimethylstyrene $e^{c}$ & $\mathrm{C}_{10} \mathrm{H}_{12}$ \\
\hline$p$-Methylcumene ${ }^{c}$ & $\mathrm{C}_{10} \mathrm{H}_{14}$ \\
\hline$o$-Allyltoluene $e^{\mathrm{c}}$ & $\mathrm{C}_{10} \mathrm{H}_{12}$ \\
\hline 2-Butenylbenzene & $\mathrm{C}_{10} \mathrm{H}_{12}$ \\
\hline$\alpha, p$-Dimethylstyrene $e^{c}$ & $\mathrm{C}_{10} \mathrm{H}_{12}$ \\
\hline$p$-Ethylcumene $e^{c}$ & $\mathrm{C}_{11} \mathrm{H}_{16}$ \\
\hline 2-Phenyl-2-pentene & $\mathrm{C}_{11} \mathrm{H}_{14}$ \\
\hline 2,4-Dimethylcumene $e^{c}$ & $\mathrm{C}_{11} \mathrm{H}_{16}$ \\
\hline 1-Methylindene $\mathrm{e}^{\mathrm{b}}$ & $\mathrm{C}_{10} \mathrm{H}_{10}$ \\
\hline$o$-Isopropyl- $\alpha$-methylstyrene ${ }^{c}$ & $\mathrm{C}_{12} \mathrm{H}_{16}$ \\
\hline Phenoprene ${ }^{c}$ & $\mathrm{C}_{10} \mathrm{H}_{10}$ \\
\hline Pentylbenzene ${ }^{b}$ & $\mathrm{C}_{11} \mathrm{H}_{16}$ \\
\hline 1,2-Dihydronaphthalene ${ }^{\mathrm{b}}$ & $\mathrm{C}_{10} \mathrm{H}_{10}$ \\
\hline$p$-Isobutyltoluene $\mathrm{e}^{\mathrm{b}}$ & $\mathrm{C}_{11} \mathrm{H}_{16}$ \\
\hline 3-Phenyl-2-pentene $e^{c}$ & $\mathrm{C}_{11} \mathrm{H}_{14}$ \\
\hline 1,1-Dimethylindene & $\mathrm{C}_{11} \mathrm{H}_{12}$ \\
\hline Trimethyl(1-methylethyl)benzene $e^{c}$ & $\mathrm{C}_{12} \mathrm{H}_{18}$ \\
\hline 2,3-Dihydro-1,1,6-trimethylindene $\mathrm{c}^{\mathrm{c}}$ & $\mathrm{C}_{12} \mathrm{H}_{16}$ \\
\hline 1,4-Dimethyltetralin ${ }^{c}$ & $\mathrm{C}_{12} \mathrm{H}_{16}$ \\
\hline 1,3-Dimethylindene $e^{\mathrm{c}}$ and 4,7-dimethylindene $\mathrm{c}^{\mathrm{c}}$ & $\mathrm{C}_{11} \mathrm{H}_{12}$ \\
\hline 1,2-Diethyl-3,4-dimethylbenzene ${ }^{c}$ & $\mathrm{C}_{12} \mathrm{H}_{18}$ \\
\hline Hexylbenzene $^{\mathrm{b}}$ & $\mathrm{C}_{12} \mathrm{H}_{18}$ \\
\hline (1-Methylbuta-1,3-dienyl)benzene ${ }^{c}$ & $\mathrm{C}_{11} \mathrm{H}_{12}$ \\
\hline 1,2-Dihydro-3-methylnaphthalene $e^{\mathrm{c}}$ & $\mathrm{C}_{11} \mathrm{H}_{12}$ \\
\hline $1,1,3$-Trimethylindene $e^{c}$ & $\mathrm{C}_{12} \mathrm{H}_{14}$ \\
\hline$\beta, 2,4,6$-Tetramethylstyrene ${ }^{c}$ & $\mathrm{C}_{12} \mathrm{H}_{16}$ \\
\hline 1,1,6-Trimethyltetralin ${ }^{c}$ & $\mathrm{C}_{13} \mathrm{H}_{18}$ \\
\hline 1-Phenyl-1,3-hexadiene ${ }^{c}$ & $\mathrm{C}_{12} \mathrm{H}_{14}$ \\
\hline Heptylbenzene $^{\mathrm{b}}$ & $\mathrm{C}_{13} \mathrm{H}_{20}$ \\
\hline$o$-Hexyltoluene $\mathrm{e}^{\mathrm{b}}$ & $\mathrm{C}_{13} \mathrm{H}_{20}$ \\
\hline$\left(2,4,6\right.$-Trimethylphenyl)allene $e^{c}$ & $\mathrm{C}_{12} \mathrm{H}_{14}$ \\
\hline 1,1-Dimethyl-3-vinylindan ${ }^{c}$ & $\mathrm{C}_{13} \mathrm{H}_{16}$ \\
\hline Octylbenzene $^{\mathrm{b}}$ & $\mathrm{C}_{14} \mathrm{H}_{22}$ \\
\hline 3-Ethyl-1-(1-methylethyl)indene ${ }^{c}$ & $\mathrm{C}_{14} \mathrm{H}_{18}$ \\
\hline Nonylbenzene $^{\mathrm{b}}$ & $\mathrm{C}_{15} \mathrm{H}_{24}$ \\
\hline Decylbenzene $e^{\mathrm{b}}$ & $\mathrm{C}_{16} \mathrm{H}_{26}$ \\
\hline Methyl-1-methyleneoctahydrophenanthrene $\mathrm{e}^{\mathrm{c}}$ & $\mathrm{C}_{16} \mathrm{H}_{20}$ \\
\hline Undecylbenzene $^{\mathrm{b}}$ & $\mathrm{C}_{17} \mathrm{H}_{28}$ \\
\hline 4,8-Diethyl-1,5-dimethyldicyclopenta $[a, d]$ benzene $^{c}$ & $\mathrm{C}_{18} \mathrm{H}_{26}$ \\
\hline
\end{tabular}

TABle 3: Continued.

\begin{tabular}{|c|c|}
\hline \multicolumn{2}{|l|}{ Aromatics, two benzene rings } \\
\hline Naphthalene & $\mathrm{C}_{10} \mathrm{H}_{8}$ \\
\hline$\alpha$-Methylnaphthalene and $\beta$-methylnaphthalene & $\mathrm{C}_{11} \mathrm{H}_{10}$ \\
\hline 1,3-Dimethylnaphthalene and & \\
\hline 2,6-dimethylnaphthalene $e^{c}$ & $\begin{array}{l}\mathrm{C}_{12} \mathrm{H}_{12} \\
\mathrm{C}_{12} \mathrm{H}_{12}\end{array}$ \\
\hline 1-Ethylnaphthalene $e^{c}$ & \\
\hline 2-Ethenylnaphthalene $e^{c}$ & $\mathrm{C}_{12} \mathrm{H}_{10}$ \\
\hline 2-(1-Methylethyl)naphthalene $e^{c}$ & $\mathrm{C}_{13} \mathrm{H}_{14}$ \\
\hline 1,4,5-Trimethylnaphthalene $\mathrm{c}^{\mathrm{c}}$ & $\mathrm{C}_{13} \mathrm{H}_{14}$ \\
\hline 1,2,3,4-Tetramethylnaphthalene $e^{c}$ & $\mathrm{C}_{14} \mathrm{H}_{16}$ \\
\hline 1-Methyl-7-(1-methylethyl)naphthalene $e^{\mathrm{c}}$ & $\mathrm{C}_{14} \mathrm{H}_{16}$ \\
\hline $4,4^{\prime}$-Dimethyl-1, $1^{\prime}$-biphenyl ${ }^{c}$ & $\mathrm{C}_{14} \mathrm{H}_{14}$ \\
\hline 1,6-Dimethyl-4-(1-methylethyl)naphthalene $e^{c}$ & $\mathrm{C}_{15} \mathrm{H}_{18}$ \\
\hline 9,10-Dihydro-1-methylphenanthrene $e^{c}$ & $\mathrm{C}_{15} \mathrm{H}_{16}$ \\
\hline 1,1-Diphenyl-1,3-pentadiene $e^{c}$ & $\mathrm{C}_{17} \mathrm{H}_{16}$ \\
\hline $\operatorname{Bis}\left(1-\right.$ methylethyl)-1, $1^{\prime}$-biphenyl ${ }^{\mathrm{c}}$ & $\mathrm{C}_{18} \mathrm{H}_{22}$ \\
\hline 9-Butyl-1,2,3,4-tetrahydroanthracene $e^{c}$ & $\mathrm{C}_{18} \mathrm{H}_{22}$ \\
\hline \multicolumn{2}{|l|}{ Aromatics, three benzene rings } \\
\hline 1-Methyl-phenanthrene ${ }^{\mathrm{c}}$ & $\mathrm{C}_{15} \mathrm{H}_{12}$ \\
\hline 2,3,5-Trimethylphenanthrene ${ }^{c}$ & $\mathrm{C}_{17} \mathrm{H}_{16}$ \\
\hline 1-Methyl-7-(1-methylethyl)phenanthrene $e^{\mathrm{c}}$ & $\mathrm{C}_{18} \mathrm{H}_{18}$ \\
\hline Methyl- $n$-propylphenanthrene $e^{\mathrm{c}}$ & $\mathrm{C}_{18} \mathrm{H}_{18}$ \\
\hline \multicolumn{2}{|l|}{ Phenolics and other oxygen containing aromatics } \\
\hline Phenol $^{\mathrm{b}}$ & $\mathrm{C}_{6} \mathrm{H}_{6} \mathrm{O}$ \\
\hline 2-Methylphenol ${ }^{\mathrm{c}}$ & $\mathrm{C}_{7} \mathrm{H}_{8} \mathrm{O}$ \\
\hline 2,5-Dimethylphenol ${ }^{\mathrm{c}}$ & $\mathrm{C}_{8} \mathrm{H}_{10} \mathrm{O}$ \\
\hline 1-(2,4-Dimethylphenyl)ethanone $e^{c}$ & $\mathrm{C}_{10} \mathrm{H}_{12} \mathrm{O}$ \\
\hline 4-(1-Methylethyl)benzenemethanol ${ }^{\mathrm{c}}$ & $\mathrm{C}_{10} \mathrm{H}_{14} \mathrm{O}$ \\
\hline 2,3-Dihydro-3,3-dimethylinden-1-ol ${ }^{\mathrm{c}}$ & $\mathrm{C}_{11} \mathrm{H}_{14} \mathrm{O}$ \\
\hline 1-(1,1'-Biphenyl)-4-yl-ethanone $\mathrm{c}^{\mathrm{c}}$ & $\mathrm{C}_{14} \mathrm{H}_{12} \mathrm{O}$ \\
\hline Isomaturnin ${ }^{c}$ & $\mathrm{C}_{16} \mathrm{H}_{14} \mathrm{O}_{3}$ \\
\hline
\end{tabular}

thermochemical stability of the decahydrophenanthrene ring structure. In the pyrolysis of neutralised TOR, as was also the case with neutralised TOFA, no significant amounts of phenolics were formed.

The total amount of pyrolysis products recovered from laboratory-scale pyrolysers is normally rather low, even though these products can be considered to reflect well the main chemistry involved. In our experiments, quantitative analyses indicated that the detectable amounts of liquefiable products were (expressed as \% of the initial dry solids) $1.4 \%$ from neutralised TOFA and 1.1 from neutralised TOR.

\section{Conclusions}

The main findings from this study can be summarised as follows.

(i) The composition of tall oil soap has a clear effect on the composition of pyrolysis products originating from it. The characteristic fragmentation patterns for this feedstock material can be detected. The effects 
of the main constituents in the raw material on the distribution of pyrolysis products are typically seen.

(ii) Resin-acid-containing soaps mainly result in the pronounced formation of aromatics during pyrolysis, whereas aliphatic unsaturated and saturated hydrocarbons can be principally obtained from fatty acidcontaining soaps.

(iii) When considering the possible tall oil-based production of renewable diesel, with respect to product quality (i.e., the need for low contents of aromatics and oxygen-containing compounds), fatty-acid-rich fractions seem to be more suitable feedstocks than resin-acid-rich fractions.

\section{Acknowledgments}

The authors gratefully acknowledge financial support from the Finnish Ministry of Education, within the framework of the International Doctoral Programme in Pulp and Paper Science and Technology (PaPSaT). Special thanks are due to Ms. Maria Luhtala for her skilful assistance with the analytical work. The authors wish to thank Forchem Oy from Finland for kindly providing the samples.

\section{References}

[1] B. Holmbom, "Improved gas chromatographic analysis of fatty and resin acid mixtures with special reference to tall oil," Journal of the American Oil Chemists' Society, vol. 54, no. 7, pp. 289-293, 1977.

[2] R. Alén, "Basic chemistry of wood delignification," in Forest Products Chemistry, P. Stenius, Ed., p. 59, Fapet Oy, Helsinki, Finland, 2000.

[3] R. Alén, "Principles in biorefining," in Biorefining of Forest Resources, R. Alén, Ed., pp. 55-114, Paperi ja Puu Oy, Helsinki, Finland, 2011.

[4] B. Holmbom and R. Ekman, Tall Oil Precursors of Scots Pine and Common Spruce and Their Change During Sulphate Pulping, vol. 38 of Acta Academiae Aboensis B, Åbo Akademi, 1978.

[5] B. Holmbom and E. Avela, Studies on Tall Oil from Pine and Birch 1. Composition of Fatty and Resin Acids in Sulfate Soaps and in Crude Tall Oils, vol. 31 of Acta Academiae Aboensis, Åbo Akademi, 1971.

[6] B. Holmbom, "The behavior of resin acids during tall oil distillation," Journal of the American Oil Chemists' Society, vol. 55, no. 12, pp. 876-880, 1978.

[7] P. Valto, J. Knuutinen, and R. Alén, "Fast analysis of relative levels of dehydroabietic acid in papermaking process waters by on-line sample enrichment followed by atmospheric pressure chemical ionisation-mass spectrometry (APCI-MS)," International Journal of Environmental Analytical Chemistry, vol. 88, no. 13, pp. 969-978, 2008.

[8] E. DeOliveira, R. L. Quirino, P. A. Z. Suarez, and A. G. S. Prado, "Heats of combustion of biofuels obtained by pyrolysis and by transesterification and of biofuel/diesel blends," Thermochimica Acta, vol. 450, no. 1-2, pp. 87-90, 2006.

[9] K. D. Maher, K. M. Kirkwood, M. R. Gray, and D. C. Bressler, "Pyrolytic decarboxylation and cracking of stearic acid," Industrial and Engineering Chemistry Research, vol. 47, no. 15 , pp. 5328-5336, 2008.

[10] G. W. Huber and A. Corma, "Synergies between bio- and oil refineries for the production of fuels from biomass," Angewandte Chemie, vol. 46, no. 38, pp. 7184-7201, 2007.

[11] H. Lappi and R. Alén, "Production of vegetable oil-based biofuels - thermochemical behavior of fatty acid sodium salts during pyrolysis," Journal of Analytical and Applied Pyrolysis, vol. 86, no. 2, pp. 274-280, 2009.

[12] H. Lappi and R. Alén, "Pyrolysis of vegetable oil soapspalm, olive, rapeseed and castor oils," Journal of Analytical and Applied Pyrolysis, vol. 91, no. 1, pp. 154-158, 2011.

[13] H. Lappi and R. Alén, "Pyrolysis of crude tall-oil derived products," in Bioresources, vol. 6, no. 4, pp. 5121-5138, 2011.

[14] K. M. Doll, B. K. Sharma, P. A. Z. Suarez, and S. Z. Erhan, "Comparing biofuels obtained from pyrolysis, of soybean oil or soapstock, with traditional soybean biodiesel: density, kinematic viscosity, and surface tensions," Energy and Fuels, vol. 22, no. 3, pp. 2061-2066, 2008.

[15] H. Aatola, M. Larmi, T. Sarjovaara, and S. Mikkonen, "Hydrotreated vegetable Oil (HVO) as a renewable diesel fuel: trade-off between NOx, particulate emission, and fuel consumption of a heavy duty engine," SAE International Journal of Engines, vol. 1, no. 1, pp. 1251-1262, 2009.

[16] K. D. Maher and D. C. Bressler, "Pyrolysis of triglyceride materials for the production of renewable fuels and chemicals," Bioresource Technology, vol. 98, no. 12, pp. 2351-2368, 2007.

[17] H. Dindi and L. E. Murillo, Patent application: Hydroprocessing of heavy hydrocarbon feeds in liquid-full reactors, Patent application number: 20120103868, 2012, http:// www.faqs.org/patents/app/20120103868\#b\#ixzz1wqb11fOS.

[18] X. Junming, J. Jianchun, L. Yanju, and C. Jie, "Liquid hydrocarbon fuels obtained by the pyrolysis of soybean oils," Bioresource Technology, vol. 100, no. 20, pp. 4867-4870, 2009.

[19] S. B. Jones, J. E. Holladay, C. Valkenburg et al., Production of Gasoline and Diesel from Biomass via Fast Pyrolysis, Hydrotreating and Hydrocracking: A Design Case, U.S. Department of Energy, 2009.

[20] R. Luque, L. Herrero-Davila, J. M. Campelo et al., "Biofuels: a technological perspective," Energy \& Environmental Science, vol. 1, no. 5, pp. 542-564, 2008.

[21] D. Mohan, C. U. Pittman, and P. H. Steele, "Pyrolysis of wood/biomass for bio-oil: a critical review," Energy and Fuels, vol. 20, no. 3, pp. 848-889, 2006.

[22] T. Bridgwater and K. Maniatis, "The production of biofuels by the thermochemical processing of biomass," in Molecular to Global Photosynthesis, M. D. Archer, Ed., pp. 521-595, Imperial College, Singapore, 2004.

[23] P. Bocchini, G. C. Galletti, S. Camarero, and A. T. Martinez, "Absolute quantitation of lignin pyrolysis products using an internal standard," Journal of Chromatography A, vol. 773, no. 1-2, pp. 227-232, 1997.

[24] B. Holmbom, E. Avela, and S. Pekkala, "Capillary gas chromatography-mass spectrometry of resin acids in tall oil rosin," Journal of the American Oil Chemists Society, vol. 51, no. 9, pp. 397-400, 1974.

[25] W. A. Hartgers, J. S. S. Damste, and J. W. de Leeuw, "Curiepoint pyrolysis of sodium salts of functionalized fatty acids," Journal of Analytical and Applied Pyrolysis, vol. 34, no. 2, pp. 191-217, 1995. 
[26] R. F. Severson, W. H. Schuller, and R. V. Lawernce, "Pyrolyses of certain resin acids at $800^{\circ} \mathrm{C}$," Journal of Chemical and Engineering Data, vol. 17, no. 2, pp. 250-252, 1972.

[27] S. C. Moldoveanu, "Pyrolysis of carboxylic acids," in Techniques and Instrumentation in Analytical Chemistry, S. C. Moldoveanu, Ed., pp. 471-526, Elsevier, New York, NY, USA, 2010. 

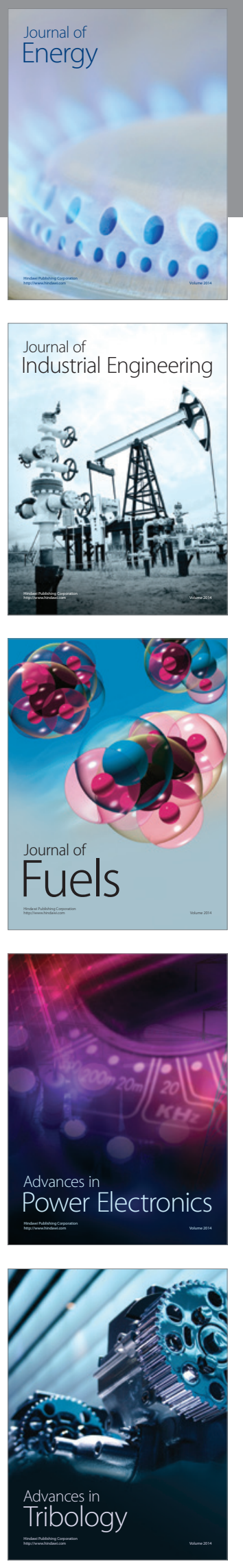
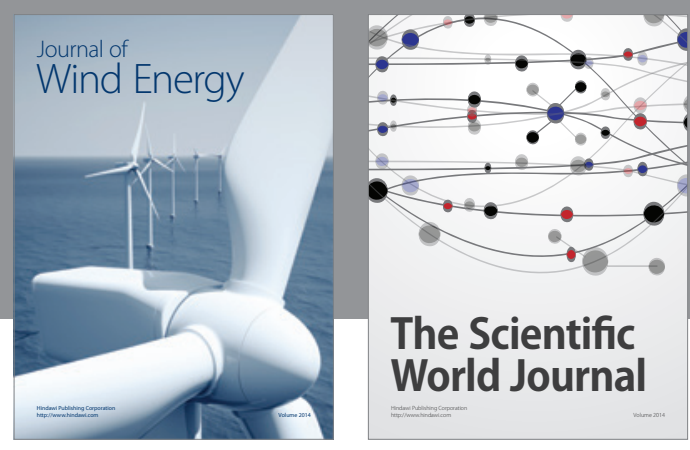

The Scientific World Journal

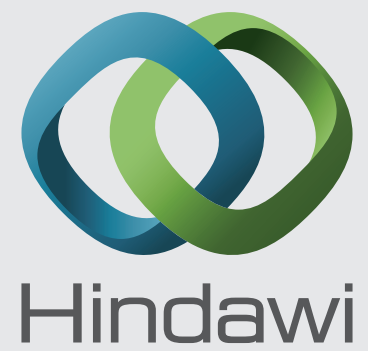

Submit your manuscripts at http://www.hindawi.com
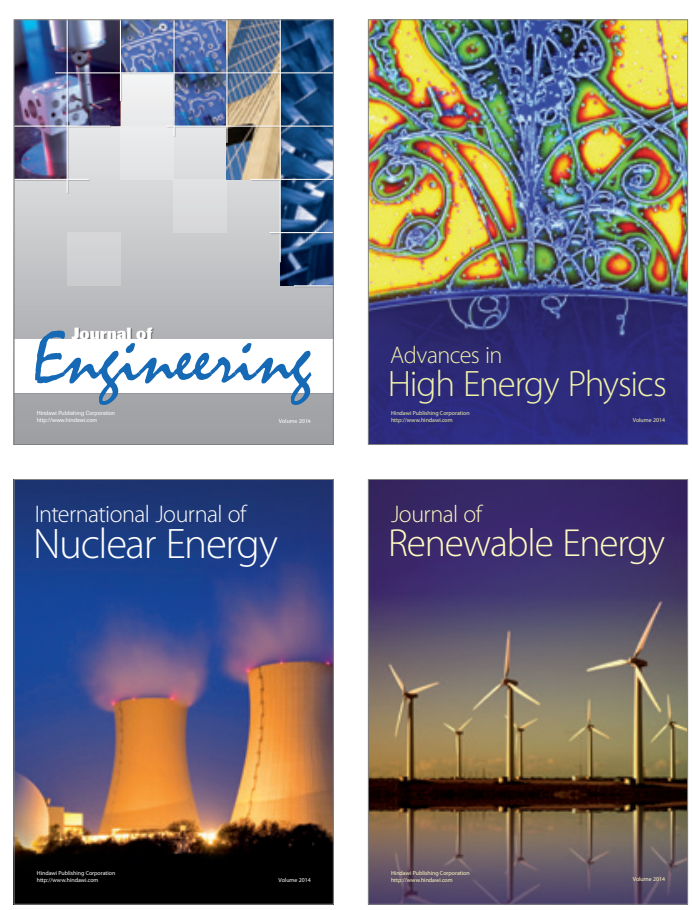

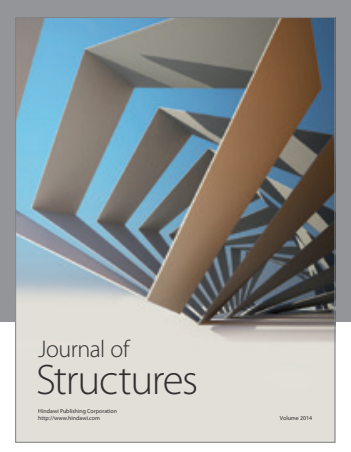

Rotating
Mechinery
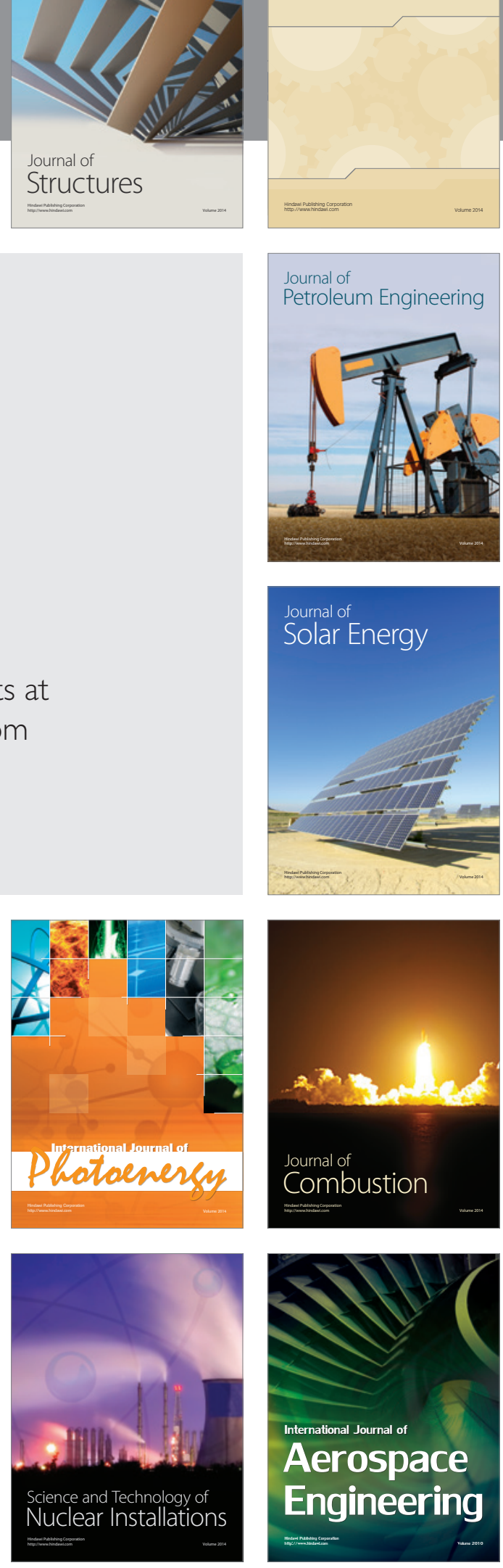